\title{
$\mathbf{P}_{4}$ 型ブラウン管（白黒テレビ受像管）の測光
}

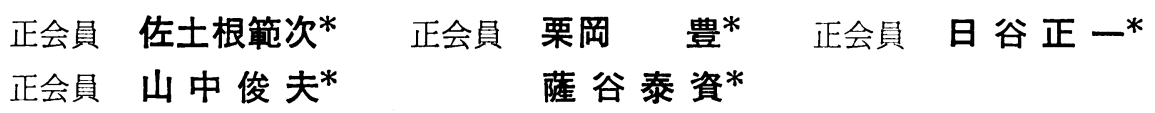

\section{The Photometry of $\mathbf{P}_{4}$ Type Television Receiving Tube}

Hanji Satone, Yutaka Kurioka, Shoichi Hitani,

Toshio Yamanaka, Taisuke Sathutani

(Osaka branchi of Electro Technical Laboratry)

\begin{abstract}
The photometry of television receiving tube has not been established, because of the particular spectral energy distribution of $\mathrm{P} 4$ type phosphor. Authors prepared a brightness standard with an incandescent lamp and glass filter. It can approximate the energy distribution of P4 type phosphor, and has been experimentally ascertained to be satisfactory as the standard for brightness-measuring instruments daily used in the photometry of a television receiving tube.

The error due to frequency response of photocell type brightness-measuring instruments and the influence of brightness-nonuniformity on the surface of the television receiving tube were also dis cussed.
\end{abstract}

\section{1. 緒言}

白黒テレビショョン受像機が各家庭にほとどん完全に普 及するに至った現在，いまだに白黒テレビションブラウ ン管の輝度の測定方式は確立されていない. その原因として次のようなものがある.

1）ブラウン管のけい光物質 $\mathrm{P}_{4}$ の発光エネルギー分 布の特異性

2）輝度測定器の分光感度の規準比視感度への一致性 の良否

3）輝度測定器の測光距離による影響

a）蔽光筒と光電池式の場合——周波応答䛊差

b）光電管とレンズ式の場合—レンズ系の距離誤差

4）ブラウン管発光面の輝度分布の非一様性

5) 輝度測定器の光電変換の直線性

6) 輝度测定器の安定性

主たる原因は 1)であるがそれ以下の要因によっても 測光誤差が生ずる。本報では電子工業会ブラウン管測光 小委員会の依頼に応じて主として 1)４）の問題につき 検討した結果を述べる.

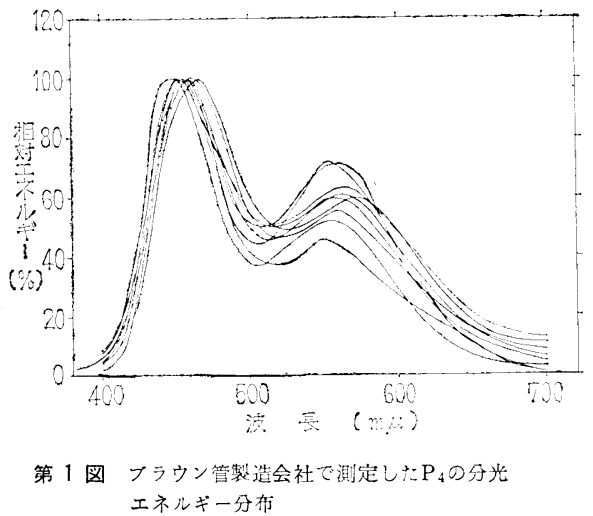

2. $\mathbf{P}_{4}$ 型けい光物質の発光エネルギー分布と 測光用標準器

$\mathrm{P}_{4}$ 型けい光物質は青色捛よび黄色けい光物質の混合 物であるため，特異な発光エネルギー分布を有する。第 1 図に示した曲線群はブラウン管測光小委員会メンバー 各社より提供された值である. 各社に扮いて青色扔よび 黄色のけい光物質の混合のしかた, 単位面積当たりの叙 布量に相違があり, 測定扔よび製品個々のバラツキも加 わっているものと思われる，したがって以後の計算には 


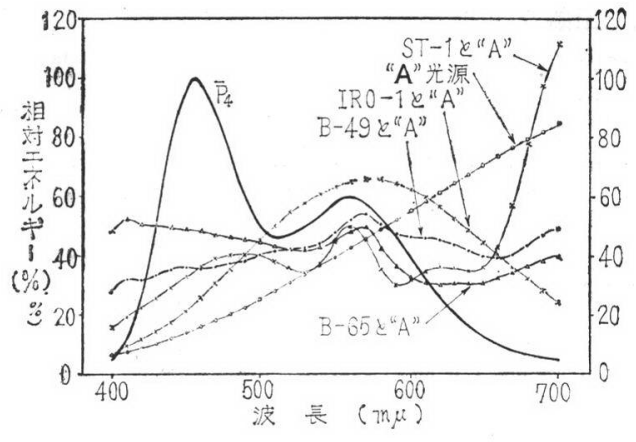

第 2 図 $\mathrm{P}_{4}$ の平均值と規準とすべき組み合わせ光源の 分光エネルギー分布

これら曲線群の平均值 $\overline{\mathrm{P}}_{4}$ 在計算して使用することにし た. 測光標準には白熱電球がよく用いられるが，この発 光エネルギー分布は $\overline{\mathrm{P}}_{4}$ のそれとは著しく異なっている ため, 受光器が比視感度曲線に適合していないと, 大き い測光䛊差を生ずるととがある。したがって測光用標準 器は適当な変換フィルタを使用して, 発光エネルギー分 布の形をできるだけ $\overline{\mathrm{P}}_{4}$ のエネルギー分布に近似させる 必要がある。

変換フィルタとして, 東芝製 IRO-1, ST-1, 保谷製 B-49, B-65 老使用し, それぞれ白熱電球（色温度 Ill “A”）と組み合わせた場合のエネルギー分布を第 2 図に 示す.とれらの分布は白熱電球だけの分布と比較すれば, かなり平担なエネルギー分布に近づいているが，ガラス フィルタ 1 枚で $\overline{\mathrm{P}}_{4}$ によく一致した分布を得るととは至 難である. 上記の変換フィルタと白熱電球の組み合わせ 光源は, 分光エネルギー分布の近似性に不満な点もある が, 輝度標準器の良さを評価するため, 輝度標準器として 使用した場合の測光誤差を計算してみる. ブラウン管拒 よび輝度標準器の分光エネルギー分布がそれぞれ $E_{p \lambda}$, $E_{s \lambda}$, 受光器の分光感度が $S_{\lambda}$ であるとすれば, ブラウ ン管の測光䛊差 $\varepsilon$ は次式のように表わされる.

$$
\varepsilon=\frac{\int_{400}^{700} E_{p \lambda}, S_{\lambda} d \lambda / \int_{400}^{700} E_{p \lambda} V \lambda d \lambda}{\int_{400}^{700} E_{s \lambda} \cdot S_{\lambda} d \lambda / \int_{400}^{700} E_{s \lambda} V \lambda d \lambda}-1
$$

ただし $V \lambda$ は規準比視感度である。

ブラウン管測光によく使用されている受光器 3 種の分 光感度を第 3 図に示す．上述の変換フィルタと白熱電球 の (IIl “A”) 組み合わせを標準器とし，ブラウン管の分 光エネルギー分布として第 2 図の $\overline{\mathrm{P}_{4}}$ の分光エネルギー 分布とした場合に, 上記 3 種の受光器について測光誤差 $\varepsilon$ を計算すると第 4 図のようになる.

てれらの結果と組み合わせ光源の色, 入手の容易さな どを考慮して保谷製フィルタ B-65 と白熱電球の組み合

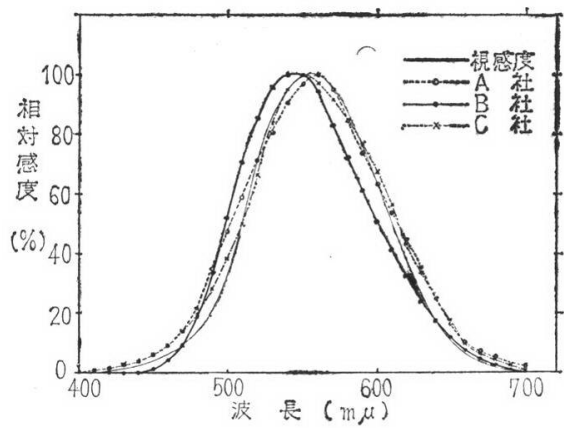

第 3 図 ブラウン管測光によく用いられている受光器感度
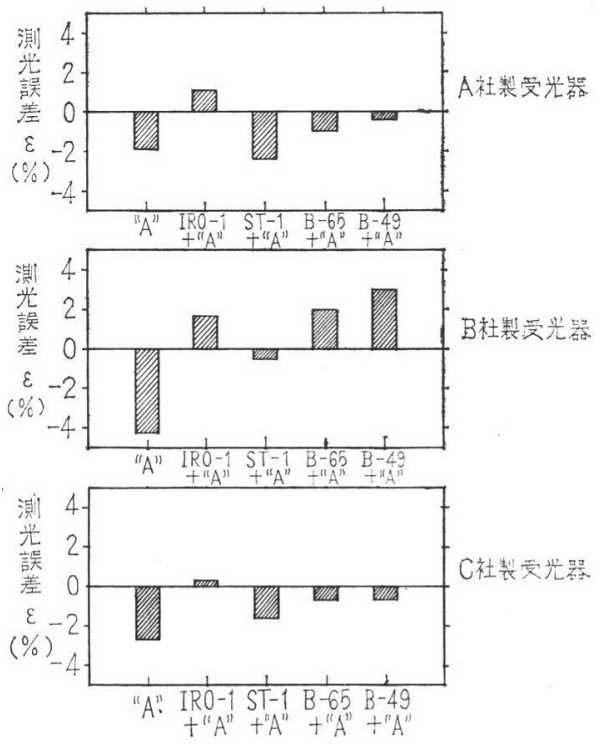

第 4 図 各種光源を標準光源として使用した場合の $\mathrm{P}_{4}$ の測光誤差

わせを標準器として使用した. 白熱電球を標準器とした ときの測光誤差は $4 \%$ を越えたのに対して，測光誤差を せいぜい $2 \%$ 程度にすることがでさる。

第 5 図招よび第 6 図に当所で試作した輝度標準器の写 真拘よびその構造図を示す，ブラウン管のけい光面の拡 散性に近づけるため, 分光的に透過率のなるべく一様な

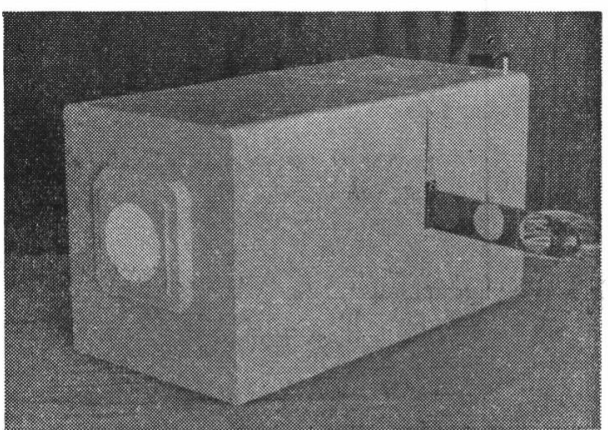

第 5 図 当所で試作した $\mathrm{P}_{4}$ 型フラウン管測光用 輝度標準器 


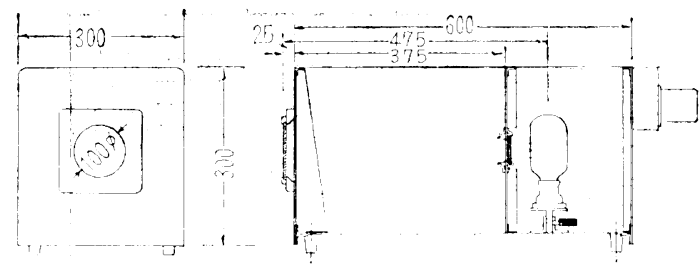

第 6 图当所で訳作した $\mathrm{P}_{4}$ 型フラウン管测光用耀度 標㭴器の權造区

白色抬散板を用い，乙の部分に標準值を付した。また内 部の温度上昇を防ぐため, ファンを使用している.

\section{3. 測光距離による影響}

レンズ式䝍度测定器の距離䛊差については文献 1) 2)に 詳細に述べられているので, ここでは光電池式輝度測定 器の周波応答誤差について検討した結果を述べる.

白黒ブラウン管のラスターは毎秒画数30枚, 1 枚の画 は526本の走査線より成るため, けい光面に残光性を有 するとはいえ，各画素は速い皹度变化怘する. 一方光電 池の周波数特性は光電池両極間の電気容量により, 入射 光の交流成分の周波数が上昇すると, 応答が平担ではな 人娢る 3) 4).

したがってブラウン管のガラス面に光電池を密着して 测定した場合, 光霆池出力が杵度の速い変化に追縦でき ないので, 応答望差を生じて光電流值が減少する.

ここで輝度標準器抢よびびブラウン管面の輝度をそれ ぞれ $B_{s}, B_{p}$, 輝度標準器打よびブラウン管を测定距離 $r$ で測定したときの光電池出力をそれぞれ $i_{s}, i_{p}$, 测光犃 差 $\varepsilon_{r}$ とすれば次式のような関係があると考えられる.

$$
\left[\frac{i_{p}}{i_{s}}\right]_{r}=\left(1+\varepsilon_{r}\right)-\frac{B_{p}}{B_{s}}
$$

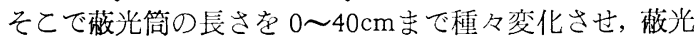
筒の各長さで 2 に述べた輝度標準器とブラウン管面を交 互に测定し, 光電流の比 $\left[i_{p} / i_{s}\right]_{r}$ を計算すると, 第 7

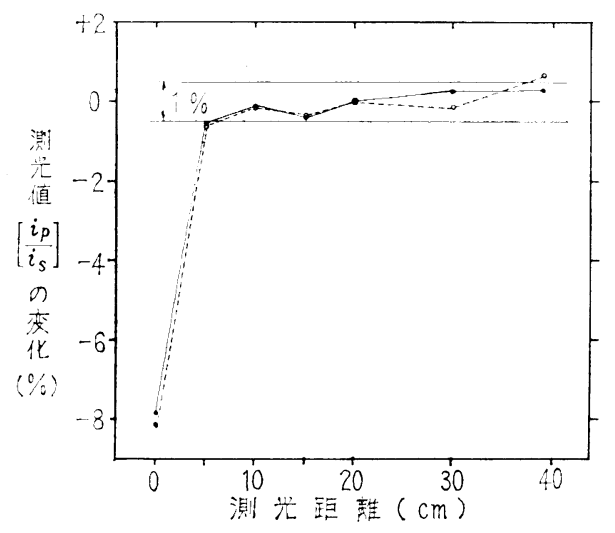

第 7 図测光距離の変化による測定值の㚆化

図のような結果が得られた。ただ受光器としてA社製 (……印)据よびB社製(一・一印)のものを使用した。
测光距離 $5 \mathrm{~cm}$ 以上では急激に $\left[i_{p} / i_{s}\right]_{r}$ の変化は少なくな っている. しかしブラウン管のガラス面に受光器を密着 した場合には测定值 $\left[i_{p} / i_{s}\right]_{r}$ が 5 40cmの場合に比へて かけ離れて低くなっていることから，测光愦差 $\varepsilon_{r}$ が大 きいと考えられる。また蔽光筒が長いほどこの種測光䛊 差は少ないと考えられるが, 光電池の感度も考慮すれば 蔽光筒の長さは10〜20cmくらいが適当であ万う。

\section{4. 輝度分布の非一様性による影響}

実験に使用したブラウン管面招よび輝度標準器の輝度 分布の一例を第 8 図に示した. $10 \mathrm{~cm} \phi$ の面積にに括け る輝度の変化が土10\%程度あり, 受光器面の感度分布の 非一様性と関連して, 测光䛊差を生ずる。

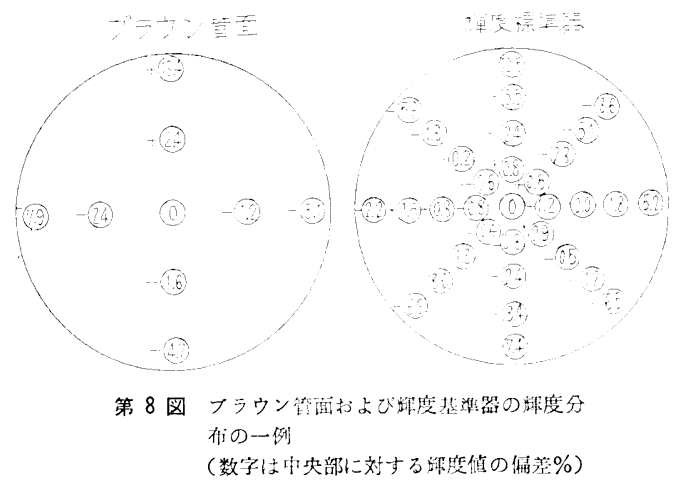

第 9 図(a)のように光電池の前方に长さ $10 \mathrm{~cm}$ の蔽光 円筒をつけ，测光面に密着する面の開口面積を $2 \mathrm{~cm} \phi$ か ら $10 \mathrm{~cm} \phi$ まで種々変化させる。このような装置を使用
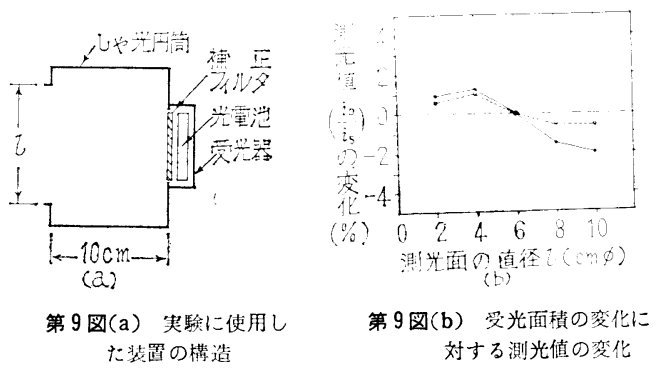

してブラウン管扰よび輝度標準器の中心部の輝度を交互 に测定した結果を第 9 図(b)に示す。ただし $i_{p}, i_{s}$ はそ れぞれブラウン管面拓よび輝度標準器の測定值であり,

$\mathrm{A}$ 社製 (…印) 扎よび $\mathrm{B}$ 社製 (一・一印) 受光器によ って実験した. 受光面積 $2 \mathrm{~cm} \phi \sim 10 \mathrm{~cm} \phi$ の変化に対して 輝度の值に $3 \%$ 程度の変化がある. 特に受光面積を大き くするとての変化が大きいように思われるので, 電子工 業会ブラウン管測光小委員会では受光面栍を $6 \mathrm{~cm} \phi$ に定 めた。 


\section{5. ブラウン管輝度の測定結果}

2 で選定したフィルタと白熱電球の組み合わせ光源 を, 通常使用されている輝度測定器の標準器として使用 した場合に，その正確さを確かめて抢く必要がある。 そ こで電子工業会ブラウン管測光小委員会のメンバーによ って, ブラウン管測光に日常使用している受光器を用い てブラウン管を測光し，測定値のバラッキを検討した。 その結果を第 10 図に示す。

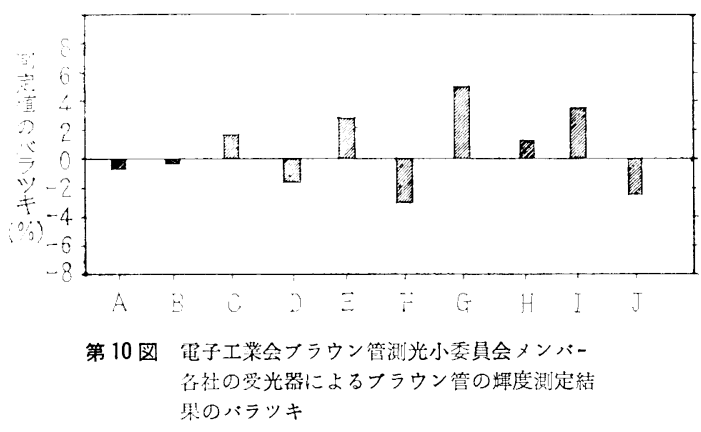

受光器は光雭池型 8 種と光電管式 2 種であり, 蔽光筒 の長さは $10 \mathrm{~cm}$, 受光面の直径は $4 \sim 7 \mathrm{~cm} \phi$ であった。 ま た光電流の直線性を良くするため, キャンベル・フリー スの回路孛使用した.

な招当所製の標準受光器 (5よるる測定值を規準値に用 いた. この受光器の分光感度は規準の比視感度にほとん どよく一致している.

測光值の変化は土5\%以内であり, ほぼ希望の正確さ が得られたので, 今後この種輝度標準器を多数製作し, 各社に 1 個ずつ配布して各社の輝度標準を維持していく ことになった。

な招この実験の際メンバーの1人が持参されたNBS
の輝度橴準器6) を使用して, 当所の輝度標準の絶対值を 比較した結果, その差が $1 \%$ 以内であり, 非常によく一 致した。 またこの標準器を使用して委員会メンバー中, 数社の受光器で, 上述のような輝度值のバラッキを検討 したととろ, 当所試作の輝度標準器の場合とほぼ同じ程 度の結果を得た。

\section{6. 結言および謝辞}

本報で得られた結諭は次のようである。

1） $\mathrm{P}_{4}$ 型ブラウン管の测光を確立するため， $\mathrm{P}_{4}$ 型ブ ラウン管の発光エネルギー分布に近似した白熱電球と保 谷ガラス製フィルタ B-65 の組み合わせ光源を標準器に 採用した，総合的な測光䛊差は実験によれば士5\%以内 でほぼ満足な絬果孛得た。

2) $\mathrm{P}_{4}$ 型ブラウン管を测光する場合, 光電池式測光器 の测光距離は 10〜20 cmくらいが適当である.

3）ブラウン管扔よび輝度標準器の輝度分布が一様で ないため, 测光器の受光面積は $6 \mathrm{~cm} \oint$ くいが適当で ある。

最後に貴重なデータの提供ならびに実験にご協力頂い た電子工業会ブラウン管測光委員会メンバーのかたがた に感謝の意を表する。

\section{参考 交 献}

（1）阪口忠雄; 照学誌 44 (昭35) 562

（2）川炏宽一，薩谷泰資；照学誌 44 (昭35) 587

(3) V.K. Zworykin : Photoelectrcity (1950) 211

（4）小黒正光; 東芝レビュー 13 (1958) 1007

（5）川畑宽一, 中村博一; 電試彙 21 (昭32) 897

（5）西沢令智, 福田 寬; テレビ学誌 16 (1962) 476

（昭和37.12.13 受付） 